\title{
Evaluation of Shear Bond Strength of Resin-Based CAD/CAM Blocks Repaired with Resin Composite
}

\author{
Rezin Kompozit ile Tamir Edilen CAD/CAM Bloklarının Bağlanma Dayanımının \\ Değerlendirilmesi
}

Ezgi Tüter Bayraktar ${ }^{\circledR}$, Ayşe Aslı Şenol ${ }^{1}$, Pınar Yılmaz Atalı ${ }^{\circledR}$, Bilge Tarçın² ${ }^{\mathbb{D}}$, Cafer Türkmen $^{3}$

\begin{abstract}
Objectives: Shear bond strength (SBS) of repaired resin-based $\mathrm{CAD} / \mathrm{CAM}$ blocks with a resin composite were evaluated in this in-vitro study.

Materials and Methods: Resin-based CAD/CAM blocks (Hc Block, Shofu; Cerasmart, GC corp.; Lava Ultimate, 3M; Brilliant Crios, Coltene) were used $(\mathrm{n}=10)$. Specimens were prepared and aged with thermocycling. Specimens were roughened by using diamond burs and adhesive agent (OptiBond Universal, Kerr) was applied. Resin composite material was placed onto the roughened surface by using silicone molds for the repair procedure. After 24 hours, second thermocycling procedure was applied and loaded in an AGS-X Universal testing machine (Shimadzu; crosshead speed of $1 \mathrm{~mm} / \mathrm{min}$ ) until failure occurred. Leica MZ 75 stereomicroscope (Leica Microsystems; 20x magnification) was used for the determination of failure type. Kruskal Wallis, Kolmogorov-Smirnov and Fisher's Exact tests were used for statistical analysis $(\mathrm{p}<0.05)$.

Results: Failure type differences were not statistically significant for the tested groups $(\mathrm{p}<0.05)$; however, multiple comparisons for the Cerasmart-Lava Ultimate and Cerasmart-Hc Block groups showed statistically significant differences $(\mathrm{p}<0.05)$. The highest SBS was measured for the Hc Block group (12.2 \pm 7.6 $\mathrm{MPa})$ whereas the lowest was for the Cerasmart group $(5.1 \pm 4.8$ $\mathrm{MPa})$.
\end{abstract}

\footnotetext{
Ezgi Tüter Bayraktar (凶)

DDS (Restorative Dentistry Specialist) Marmara University Faculty of Dentistry, Department of Restorative Dentistry, 9/3, 34854 Maltepel Istanbul.

e-mail: tuterezgi@gmail.com

Ayşe Aslı Şenol

DDS (Restorative Dentistry Specialist) Marmara University Faculty of Dentistry, Department of Restorative Dentistry.

Pınar Yılmaz Atalı, Bilge Tarçın

Associate Professor, Marmara University Faculty of Dentistry, Department of Restorative Dentistry.

Cafer Türkmen

Professor, Marmara University Faculty of Dentistry, Department of Restorative Dentistry.
}

Submitted / Gönderilme: 11.11.2021

Accepted/Kabul: 07.12.2021
Conclusions: Within the limitations of this study, the type of resin-based CAD/CAM blocks affected the SBS values of repaired restorative materials and the bond strength of repaired Cerasmart blocks was lower than those obtained in the other three CAD/CAM blocks.

Keywords: CAD/CAM Block, Repair, Shear Bond Strength Öz

Amaç: $\mathrm{Bu}$ çalışmada, universal adeziv sistem kullanılarak, nano-hibrit rezin kompozit ile tamir edilen CAD/CAM blokların bağlanma dayanımı (SBS) değerlendirilmiştir.

Gereç ve Yöntemler: Dört rezin esaslı CAD/CAM blok (Hc Block, Shofu; Cerasmart, GC corp.; Lava Ultimate, 3M; Brilliant Crios, Coltene) kullanılarak $3 \mathrm{~mm}$ kalınlığında numuneler hazırlandı $(n=10)$. Bitim işlemi uygulanan numuneler termal siklus ile yaşlandırıldıktan sonra elmas frezler ile pürüzlendirildi. Self-etch modunda universal bir adeziv ajan (OptiBond Universal, Kerr) uygulandı. Tamir için rezin kompozit materyal (Harmonize, Kerr) silikon kalıplara yerleştirildi, polimerize edildi ve 24 saat bekletildi. İlave termal siklus prosedürünü takiben universal test cihazında (AGS-X Universal, Shimadzu) kopma oluşana kadar yük uyguland1. Kopma tipi stereomikroskop (Leica MZ 75, Leica Microsystems) kullanılarak 20x büyütme altında belirlendi. İstatistiksel analiz Fisher's Exact, Kolmogorov-Smirnov ve Kruskal Wallis testleri ile yapıld $1(\mathrm{p}<0,05)$.

Bulgular: Test edilen gruplar için kopma tipleri arasındaki fark istatistiksel olarak anlamlı değildi $(\mathrm{p}<0,05)$. Cerasmart-Lava Ultimate, Cerasmart-Hc Block grupları arasındaki fark istatistiksel olarak anlamlıydı $(p<0,05)$. En yüksek SBS değeri Hc Blok grubunda (12.2 $\pm 7.6 \mathrm{MPa})$ ölçülürken, en düşük değer Cerasmart grubunda $(5,1 \pm 4.8 \mathrm{MPa})$ gözlenmiştir.

Sonuçlar: $\mathrm{Bu}$ çalışma şartları altında, rezin easalı CAD/ CAM blok tipi tamir uygulamasında SBS değerini etkilemiştir. Harmonize kompozit ile tamir edilen Cerasmart bloklarda diğer üç CAD/CAM blok tamirinde elde edilen bağlanma dayanımına ulaşılmamıştır.

Anahtar Kelimeler: CAD/CAM Blok, Makaslama Bağlanma Dayanımı, Tamir 


\section{Introduction}

Computer-aided design/Computer-aided manufacturing (CAD/CAM) technology is commonly used in dentistry for high standard, long term restorations. Designing and manufacturing steps for the restoration can be performed both in dental clinic and laboratory. CAD/CAM systems can eliminate the need for temporary restorations by reducing the treatment time (Stawarzyck et al., 2015). CAD/CAM blocks have higher mechanical and optical properties than resin composites. CAD/CAM blocks are more resistant to wear and discoloration and these properties help to provide long-term clinical usage (Edelhoff et al., 2012).

On the other hand, in addition to all these advantages $\mathrm{CAD} / \mathrm{CAM}$ materials have some limitations. Internal stresses, porosity in the restoration due to faulty production, inadequate interconnection between tooth tissue and restoration, inconvenient occlusal relationship and parafunctional habits may cause fractures in CAD/CAM restorations (Gul \& Altınok Uygun, 2020). When fracture occurs, replacement of the restoration is not be the best convenient way. Removal of the restoration may cause an increase in the preparation area and it means loss of more healthy dental tissue (Rekow et al., 2011). For this reason, direct repair with resin composite is a more convenient way in terms of both obtaining faster results and protecting healthy dental tissue (Loomans \& Özcan, 2016). The selection of the adhesive agent, restorative material and surface preparation is the basis of the repair procedure (Arhun \& Tuncer, 2017). There are many options for repairing $\mathrm{CAD} / \mathrm{CAM}$ restorations with resin composite. These options are including different surface treatments, adhesive systems and resin composites (Elsaka, 2015). The repair procedure includes mechanical and chemical treatments on the restoration surface to create surface irregularities, high surface energy, and thus obtain adequate bond strength (Sismanoglu et al., 2020). Although there is no standard protocol for the repair procedure of resin-based CAD/CAM blocks, many studies have included air abrasion and grinding by diamond bur for mechanical surface pretreatment (Duzyol et al., 2016; Bayraktar et al., 2021; Stawarczyk et al., 2015). As the success of the repair can be affected by different material combinations, studies including repair with different types of resin composites are considerable for the clinical success.

Different types of resin composites can be used for the direct repair procedure. Nano-hybrid resin composites have advantages owing to their high filler content and nanosized filler particles. These advantages are easy handling, low polymerization shrinkage, superior polishability and esthetic properties (Alagha, 2020). For the repair procedure to be successful, a strong bond between the resin composite and the old restoration is essential (Altınc1 et al., 2018).

To predict the clinical success of the repaired restoration, it is necessary to simulate the oral environment. Thermal cycling is an artificial aging technique of restorative materials which is desired to test the effect of fluids and thermal changes on bond strength (Rinastiti et al., 2011). The shear test subjected in this study is used in many studies to evaluate the repair bond strength (Stawarczyk et al., 2015; Jeong \& Kim, 2019).

The null hypotheses of this study are, $\left(\mathrm{h}_{0}\right)$ Failure type is similar among the tested groups, $\left(\mathrm{h}_{1}\right)$ there would be no differences in shear bond strength values (SBS) among the tested resin-based CAD/CAM blocks.

\section{Materials and Methods}

Four resin-based CAD/CAM blocks (Hc Block, Shofu; Brilliant Crios, Coltene; Cerasmart, GC corp.; Lava Ultimate, 3M) were used for their bond strength after the repair procedure (Table 1). CAD/CAM blocks were prepared by using a low-speed diamond saw (Isomet, Buehler Ltd., USA) under water cooling. A total of 40 samples with a thickness of $3 \mathrm{~mm}$ were prepared $(\mathrm{n}=10$; Sismanoglu et al., 2020). The samples were exposed to a thermo-cycling protocol with 1500 cycles $\left(5-55^{\circ} \mathrm{C}\right.$, dwell time $20 \mathrm{~s}$ ) to mimic the oral environment (Zanatta et al., 2017). The surfaces of the specimens to be repaired were standardized for $15 \mathrm{~s}$ with silicon carbide abrasive papers (600, 800, 1200-grit), under running water $(170 \mathrm{rev} / \mathrm{m}$; Minitech 233, Presi, France) and kept in distilled water for 24 hours (Ozcan et al., 2013). The standardized surfaces of the specimens were mechanically treated with $125 \mu \mathrm{m}$ grain size diamond burs (1292/879; Adia, Turkey; Figure 1) for $5 \mathrm{~s}$ at high speed under copious air/water spray to prepare for the repair protocol. Diamond burs were renewed after every 5 specimens to provide similar roughening procedure. Universal adhesive system (OptiBond Universal, Kerr, USA; Figure 2) and a nanohybrid universal composite (Harmonize, Kerr) were used for the repair procedure. Following the application of the universal adhesive (OptiBond Universal, Kerr) in self-etch mode, $2 \mathrm{~mm}$ composite layers were placed using a silicone mold (Figure 3) and polymerized with Valo Cordless curing device (Ultradent, USA) in standard mode $\left(1000 \mathrm{~mW} / \mathrm{cm}^{2}\right.$ for $20 \mathrm{~s}$; Figure 4-5). After the repair 
procedure was completed, the specimens were immersed in distilled water for 24 hours and thermal cycling was repeated to artificially mimic the aging of the repaired restoration (1,500 cycles; $5-55{ }^{\circ} \mathrm{C}$; dwell time, $20 \mathrm{~s}$ ). Samples were mounted on a universal testing machine (AGS-X Universal, Shimadzu, Japan; Figure 6) for shear bond strength testing. A continuously increasing loading force was applied at a $1 \mathrm{~mm} / \mathrm{min}$ crosshead speed. The load was increased until failure. Failure load was recorded for each sample and calculated using the following formula: Shear bond strength $(\mathrm{MPa})=$ load at failure $(\mathrm{N}) /$ bonded surface area $\left(\mathrm{mm}^{2}\right)$ (Aquino et al., 2020). The failure type was determined with a stereomicroscope (Leica MZ 75, Leica Microsystems, Germany) under $\mathrm{x} 10$ and $\times 20$ magnification and categorized as follows: i) cohesive failure of material (fracture within the body of resin composite or fracture within the body of $\mathrm{CAD} / \mathrm{CAM}$ block), ii) adhesive failure (failure between $\mathrm{CAD} / \mathrm{CAM}$ block and a resin composite), iii) mixed failure (cohesive and interfacial failure at the same time on any side) (Gul \& Altınok-Uygun, 2020). Data were analyzed statistically by using Kolmogorov-Smirnov, Kruskal Wallis, and Fisher's Exact tests with the significance level set at $\mathrm{p}<0.05$.

Table 1: Chemical compositions of the materials used in the study.

\begin{tabular}{|c|c|c|c|}
\hline & Brands & Monomer & Filler Content \\
\hline \multirow{4}{*}{$\begin{array}{c}\text { Resin-based } \\
\text { CAD/CAM } \\
\text { block }\end{array}$} & $\begin{array}{c}\text { Hc Block } \\
\text { Shofu, Japan }\end{array}$ & $\begin{array}{l}\text { UDMA, } \\
\text { TEGDMA }\end{array}$ & $\begin{array}{l}\text { Silica-powder, } \\
\text { zirconium silicate, } \\
\text { micro fumed silica } \\
61 \%\end{array}$ \\
\hline & $\begin{array}{l}\text { Cerasmart GC } \\
\text { Corp., Japan }\end{array}$ & $\begin{array}{l}\text { Bis-MEEP, } \\
\text { UDMA, DMA }\end{array}$ & $\begin{array}{c}\text { Silica and barium } \\
\text { glass nanoparticles } \\
71 \%\end{array}$ \\
\hline & $\begin{array}{c}\text { Lava Ultimate } \\
\text { 3M, USA }\end{array}$ & $\begin{array}{l}\text { Bis-GMA, } \\
\text { UDMA, } \\
\text { Bis-EMA, } \\
\text { TEGDMA }\end{array}$ & $\begin{array}{l}\text { Silica and zirconia } \\
\text { nanoparticles } 80 \%\end{array}$ \\
\hline & $\begin{array}{l}\text { Brilliant Crios } \\
\text { Coltene, } \\
\text { Switzerland }\end{array}$ & $\begin{array}{l}\text { Bis-GMA, } \\
\text { BiS-EMA, } \\
\text { TEGDMA }\end{array}$ & $\begin{array}{l}\text { Barium glass and } \\
\text { silica particles } 71 \%\end{array}$ \\
\hline $\begin{array}{c}\text { Nano- } \\
\text { hybrid Resin } \\
\text { Composite }\end{array}$ & $\begin{array}{l}\text { Harmonize } \\
\text { Kerr, USA }\end{array}$ & $\begin{array}{l}\text { Bis-GMA, } \\
\text { Bis-EMA, } \\
\text { TEGDMA }\end{array}$ & $\begin{array}{c}\text { Silica and Zirconia } \\
81 \%\end{array}$ \\
\hline Adhesive & $\begin{array}{l}\text { Optibond } \\
\text { Universal } \\
\text { Kerr, USA }\end{array}$ & \multicolumn{2}{|c|}{$\begin{array}{l}\text { Monomer: HEMA, GPDM, Glycerol } \\
\text { dimethacrylate } \\
\text { Solvent: Acetone, Ethanol, Water }\end{array}$} \\
\hline
\end{tabular}

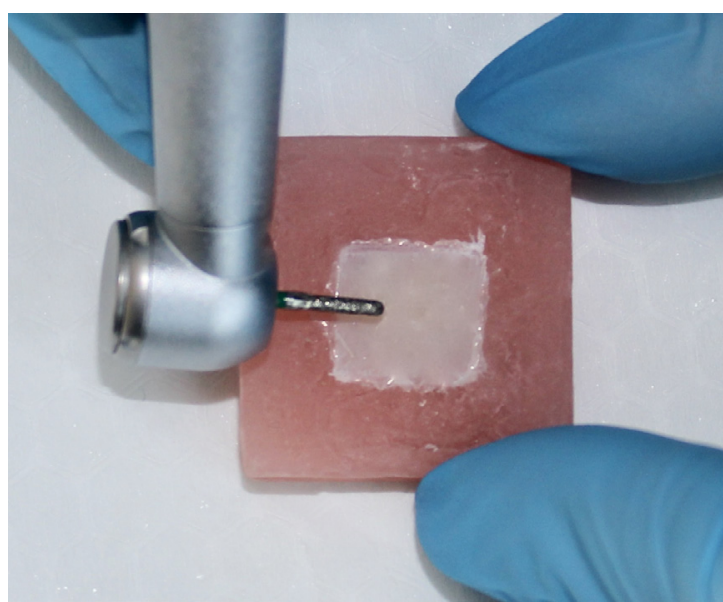

Figure 1: Roughening with diamond bur

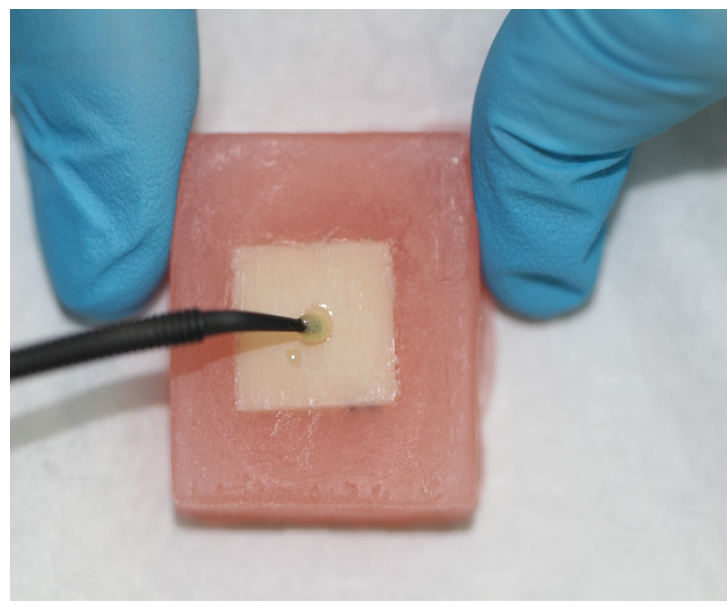

Figure 2: Adhesive agent application

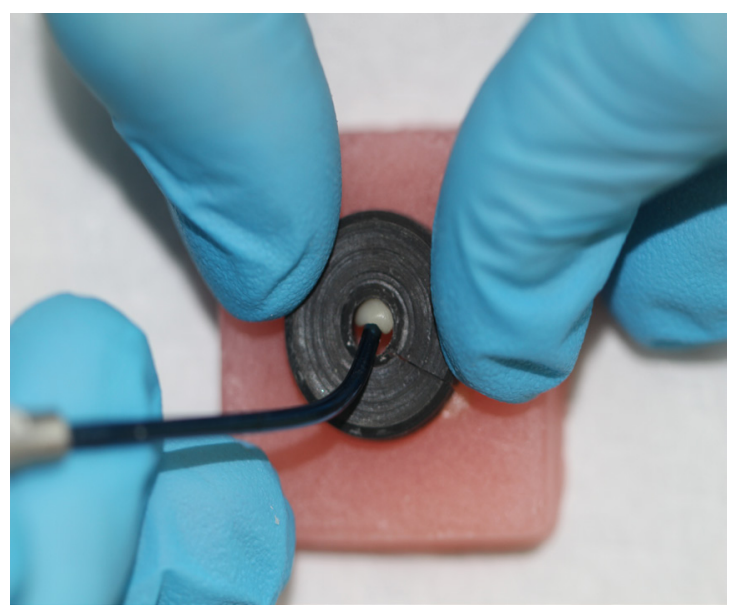

Figure 3: Placing of the resin composite 


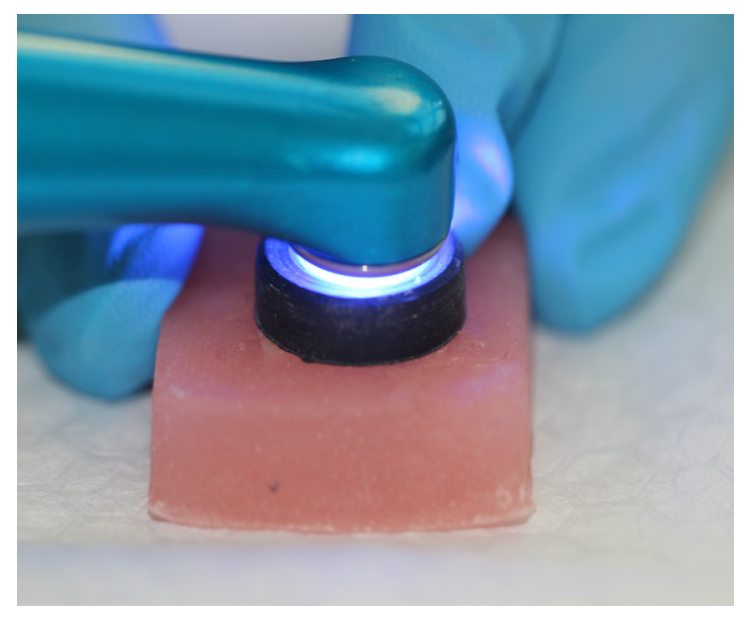

Figure 4: Polymerizing with LED curing device

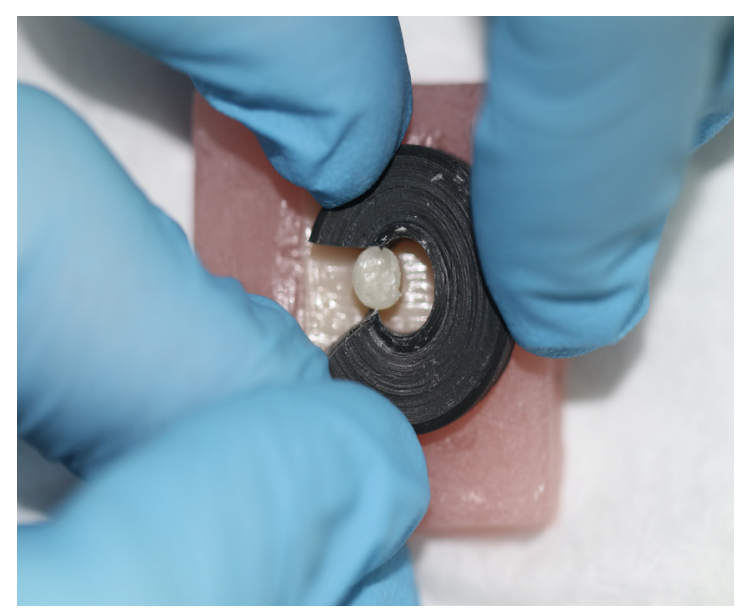

Figure 5: Removal of silicone mold

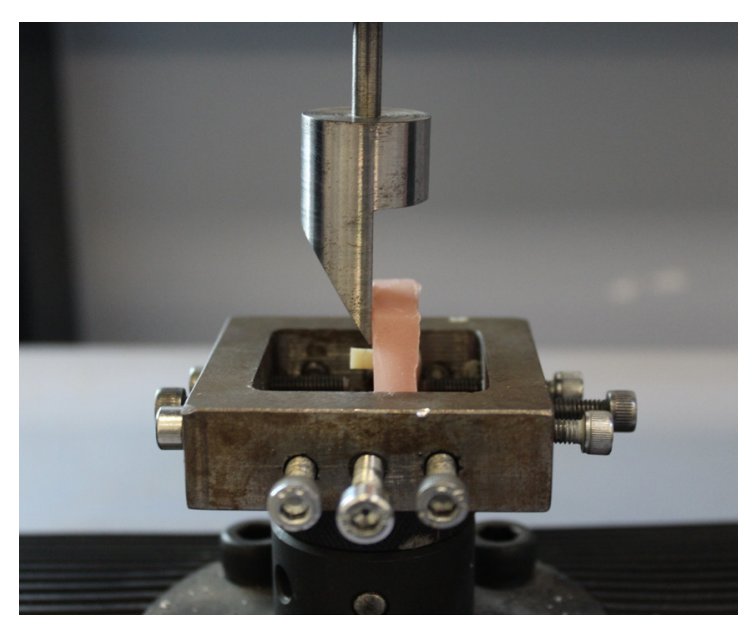

Figure 6: Loading in the shear bond testing

\section{Results}

A statistically significant difference was found among the mean SBS values of the groups $(\mathrm{p}=0.011)$. The highest SBS value was detected in the Hc Block group (12.2 \pm 7.6 $\mathrm{MPa})$, whereas the lowest in the Cerasmart group $(5.1 \pm 4.8$ $\mathrm{MPa}$ ) (Table 2; Figure 7). Statistically significant differences were found between Cerasmart-Lava Ultimate $(p=0.005)$ and Cerasmart-Hc Block groups $(\mathrm{p}=0.003)$ (Table 3$)$. Mean SBS values of the Cerasmart group $(5.1 \pm 4.8)$ were lower than HC block (12.2 \pm 7.6$)$ and Lava Ultimate (12.0 \pm 7.0$)$ groups. Differences between adhesive, cohesive and mix failure types (Figure 8; Figure 9) were not statistically significant among the tested groups $(\mathrm{p}<0.05)$.

Table 2: Difference between the mean SBS values (MPA) among the CAD/CAM blocks.

\begin{tabular}{|c|c|}
\hline Brands & Mean \pm SD \\
\hline Brilliant Crios & $9.0 \pm 6.5$ \\
\hline Cerasmart & $5.1 \pm 4.8$ \\
\hline Hc Block & $12.2 \pm 7.6$ \\
\hline Lava Ultimate & $12.0 \pm 7.0$ \\
\hline Total & $\mathbf{9 . 5} \pm \mathbf{6 . 9}$ \\
\hline p (sig.) & $\mathbf{0 . 0 1 1 *}$ \\
\hline
\end{tabular}

*Kruskal wallis test

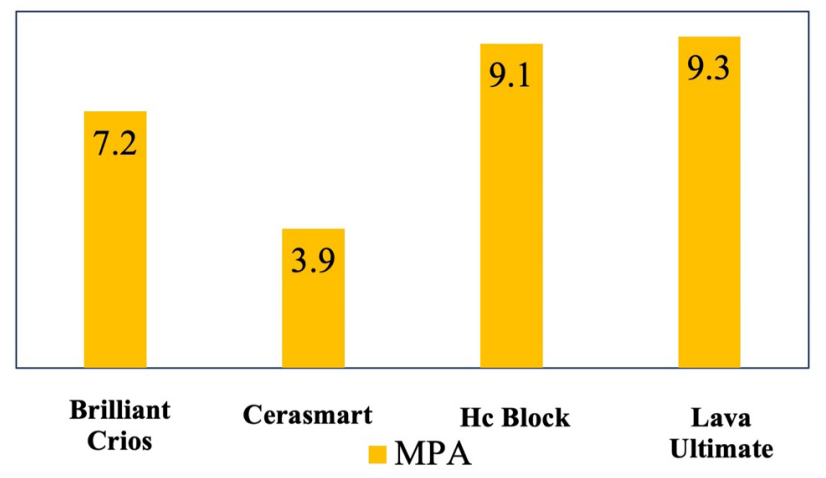

Figure 7: Mean SBS values of the groups

Table 3: Multiple comparisons of the SBS values regarding the blocks.

\begin{tabular}{|c|c|c|}
\hline Blocks & \multicolumn{2}{|c|}{ p (sig.) } \\
\hline \multirow{3}{*}{ Brilliant Crios } & Cerasmart & 0.052 \\
& Hc Block & 0.315 \\
& Lava Ultimate & 0.280 \\
\hline \multirow{2}{*}{ Cerasmart } & Hc Block & $\mathbf{0 . 0 0 3 *}$ \\
& Lava Ultimate & $\mathbf{0 . 0 0 5 *}$ \\
\hline Hc Block & Lava Ultimate & 0.842 \\
\hline
\end{tabular}

*Fisher's Exact test 


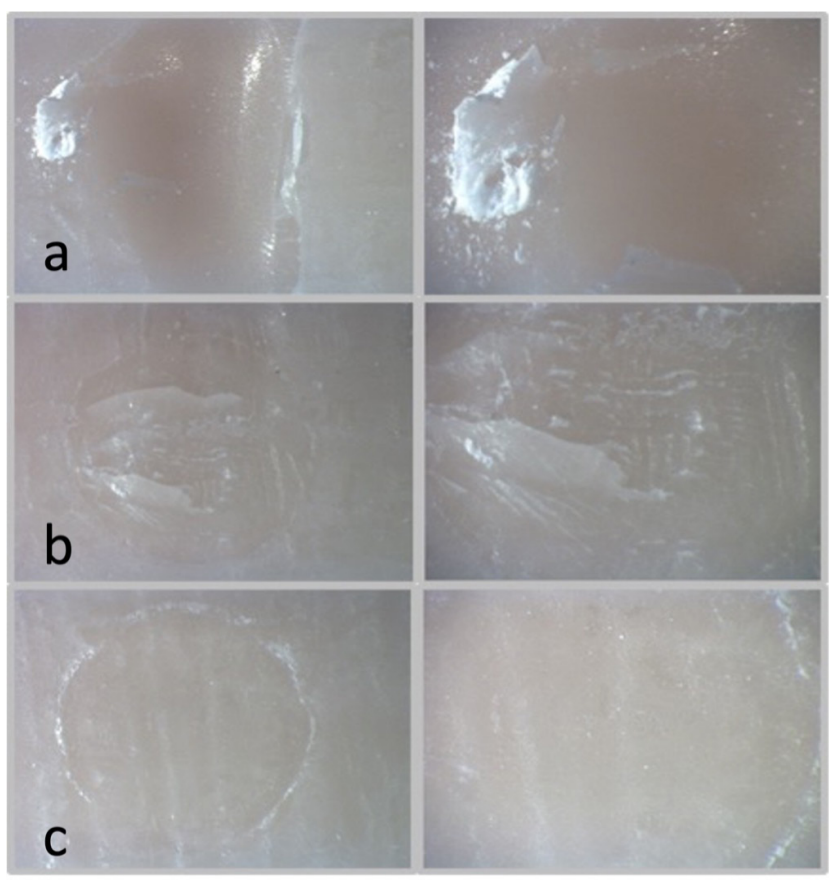

Figure 8: Evaluation of failure types $(x 10, x 20)$ a) Cohesive failure type (within the block), b) Mixed failure type (adhesive + cohesive), c) Adhesive failure type

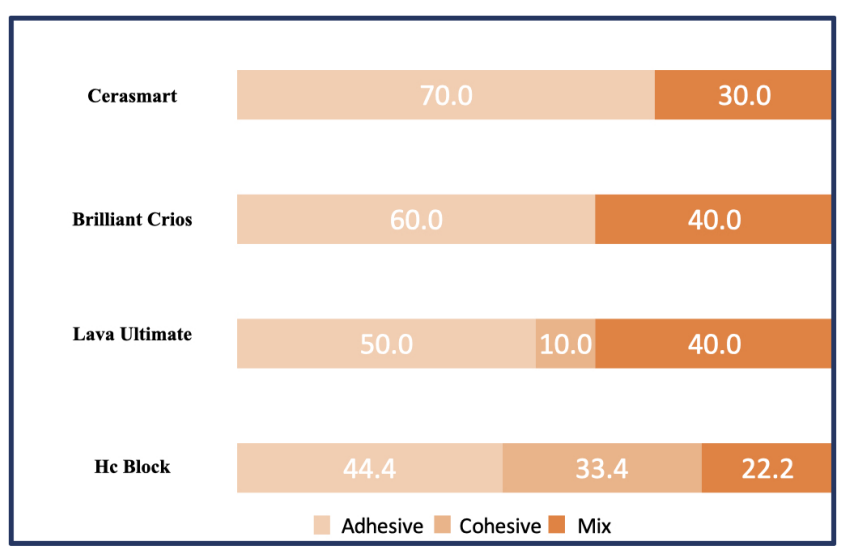

Figure 9: Comparison of failure type analysis (\%) between the groups

\section{Discussion}

Restoration fractures and chipping are frequently encountered clinical failures of the restorations (Vianna et al., 2018). Although CAD/CAM blocks show similar properties to natural tooth, various factors can cause fractures in restorations. When a clinical failure occurs, restorations are frequently replaced; however, the manufacturing of the new restoration can cause extra trauma and time loss.
In these cases, performing the repair procedure instead of replacement of the restoration may be a less costly alternative and may reduce tissue loss (Kanzow et al., 2021; Kanzow et al., 2016). Therefore, CAD/CAM restorations should be repaired directly as much as possible (Şişmanoğlu et al., 2021).

In current dental treatments, repair procedure is applied to various restorations such as amalgam, resin composite, or porcelain (Blum et al., 2014). Abrasion with diamond and carbide burs, etching, airborne particle abrasion, tribochemical silica airborne particle abrasion, silane, primer and resin adhesive applications are frequently applied methods for the surface pretreatments of various materials before repair and have been investigated in numerous laboratory studies (Kanzow et al., 2019). The steps to be followed in the repair procedure for each restoration type differ depending on its content. Strasser et al. evaluated the effects of surface pretreatment on different $\mathrm{CAD} / \mathrm{CAM}$ materials, including ceramics, zirconia, resin-infiltrated ceramics, and resin-based composites. It was stated that for optimized and protective surface activation of CAD/CAM materials with different content, special pre-treatment is required for each material (Strasser et al., 2018). However, there is no consensus yet on a standard repair protocol for $\mathrm{CAD} / \mathrm{CAM}$ resin-ceramic hybrid materials (Stawarczyk et al., 2015; Elsaka, 2015). For these reasons, in the present study, the success of repairing CAD/CAM blocks with resin composite was investigated.

$\mathrm{CAD} / \mathrm{CAM}$ blocks are polymerized under high temperature and pressure since they show higher degree of conversion (DC) than resin composites (Bayraktar et al., 2021). Despite the high temperature and pressure, resin monomers cannot reach to $100 \%$ polymer, leaving free monomers remaining in the material. Because of the unpolymerized double carbon-carbon bonds, covalent bond formation occurs between restoration and resin composite (Bayraktar et al., 2020). According to this information, repair capacity of the material increases in parallel with the resin content. In the present study CAD/CAM resin blocks were selected due to their high resin content.

Despite the low amount of unreacted $\mathrm{C}=\mathrm{C}$ bonds, as $\mathrm{CAD} / \mathrm{CAM}$ resin blocks have a higher $\mathrm{DC}$ than conventionally polymerized resins, the bond strength of the repair is significantly improved with the use of adhesive systems and surface pretreatments (Stawarczyk et al., 2015). Mechanical surface pretreatments are applied to obtain 
surface topography that increases the surface roughness and energy required for the bond strength of the repair.

In this study, grinding with diamond burs is considered as the pretreatment of the repair surface. Surface roughening with diamond bur, which is one of the mechanical surface preparation methods, has easy clinical applicability and is an accessible equipment (Arhun \& Tuncer, 2017). In the pretreatment of resin restorative materials with a bur, a rough surface emerges as a result of different wear types that occur in the organic and inorganic phase of the material with different hardness. With this rough structure, it is aimed to contribute to the mechanical interlocking between the adhesive and the repair surface. The type of wear on the surface differs according to both the restorative material and the grit size of the diamond bur (Valente et al., 2015). Strasser et al. concluded that the grinding procedure with medium-grain diamond burs can be preferred for intraoral repair of resin-based composite blocks (Cerasmart, GC Corp.; LAVA Ultimate, 3M; HC Block, Shofu; Grandio Blocs, Voco; Brilliant Crios, Coltene) (Strasser et al., 2018). Similar to other studies, Güngör et al. showed that surface treatments involving grinding using $125 \mu \mathrm{m}$ grain size diamond bur significantly increased SBS in CAD/CAM resin-ceramic hybrid materials. When the roughness values are compared, the surfaces roughened with diamond bur give the highest value, followed by the surfaces abraded with air particles (Güngör et al., 2016). In the study conducted by Bayraktar et al., the highest microtensile bond strength results in Lava Ultimate material was obtained by bur grinding (diamond bur with 107-181 $\mu \mathrm{m}$ grain size). It has been reported that resin-ceramic CAD/CAM blocks show less chip formation after surface grinding by bur than hybrid ceramic and feldspathic ceramic blocks (Bayraktar et al., 2021). Contrary to other studies, there is a study that argues that surface treatments reduce the bond strength in resin-based CAD/CAM block (Lava Ultimate, 3M) and should be avoided (Duzyol et al., 2016).

Fracture type analysis is one of the methods used to evaluate bond strength. Adhesive failure means decreased SBS, whereas cohesive failure is associated with increased SBS (Kilinc et al., 2020). In the present study adhesive failure rate is higher than cohesive and mixed failure types but the difference was not statistically significant. The hypothesis (h0) "Failure type is similar among the tested groups" was accepted.

Previous studies have shown that the degree of conversion decreases more with TEGDMA than with UDMA
(Gajewski et al., 2012). A high degree of conversion means that it contains more free monomers thereby increasing the repair capacity of the material. In the present study, Cerasmart group showed the lowest SBS value, which can be explained with its TEGDMA content. While Cerasmart does not contain TEGDMA, the other three groups have TEGDMA in their content.

The difference between the mean SBS values of Cerasmart-Lava Ultimate and Cerasmart-Hc Block groups were found to be statistically significant $(\mathrm{p}<0.05)$. Hypothesis (h1) "There would be no differences in shear bond strength values (SBS) among the tested resin-based CAD/CAM blocks." was rejected. This difference can be attributed to the TEGDMA content of Lava Ultimate and Hc block groups.

The content of the repaired restoration, the material used for the repair, and the ratio and composition of the fillers of these materials are among the important factors in repair bond strength. In the current study, nanohybrid composite was preferred as the repair composite.

Conflicting results have been obtained in studies comparing the repair bond strength of different resin-based composite materials classified according to their filler content. Zakavi et al. compared the repair bond strengths of hybrid, microhybrid, and nanofilled composites and the nanocomposite failed to produce appropriate repair bond strengths (Zakavi et al., 2021). In the study of Nassoohi et al., nanohybrid and nanofilled composites showed similar microtensile bond strength, while microhybrid composite had higher bond strength (Nassoohi et al., 2015). Özcan et al. reported that repair strength seemed to be more stable for the nanofilled resin composite than for the nanohybrid composite (Özcan et al., 2013).

In this study, CAD/CAM blocks were repaired with Optibond universal, single-component light-cured adhesive, which is a new material and studies are limited. As the glycerol phosphate dimethacrylate (GPDM) in Optibond universal has two polymerizable groups, it prones to react more strongly with the monomers in the adhesive and restorative material and shows an increased degree of conversion. A relatively high acidity of 1.9 has been reported for Optibond universal compared to other universal adhesives in the study by Aung et al (Aung et al., 2021). 


\section{Conclusion}

Within the limitations of this in-vitro study, the shear bond strength of repaired Cerasmart group was lower than the other $\mathrm{CAD} / \mathrm{CAM}$ blocks. The type of resin-based CAD/ CAM block was found to be effective on the repair bond strength.

\section{Acknowledgements}

This study was not supported by a grant or any other kind of funding.

\section{Conflicts of Interest Statement}

There is no conflict of interest for this study.

\section{References}

1. Alagha EI. Effect of using Different Remineralizing Agents on Micro-shear Bond Strength of Nanohybrid Composite Resin. Open. Access. Maced. J. Med. Sci. 2020;8(D):70-76.

2. Altinci P, Mutluay M, Tezvergil-Mutluay A. Repair bond strength of nanohybrid composite resins with a universal adhesive. Acta Biomater. Odontol. Scand. 2018;4(1):1019.

3. Aquino C, Mathias C, Barreto SC, Cavalcanti AN, Marchi GM, Mathias P. Repair bond strength and leakage of nonaged and aged bulk-fill composite. Oral Health. Prev. Dent. 2020;18(1):783-791.

4. Arhun N, Tuncer D. Dental Composite Materials for Direct Restorations. Miletic V, editors. Dental Composite Materials for Direct Restorations. Switzerland: Springer International Publishing; 2018. p. 245-267.

5. Aung SSMP, Takagaki T, Ikeda M, Tagami J. Ultramorphological studies on enamel-universal adhesive interface. J. Dent. 2021;104:103527.

6. Bayraktar Y, Arslan M, Demirtag Z. Repair bond strength and surface topography of resin-ceramic and ceramic restorative blocks treated by laser and conventional surface treatments. Microsc. Res. Tech. 2021;84(6):1145-1154.

7. Bayraktar Y, Demirtağ Z, Çeli Ç. Effect of Er: YAG laser pulse duration on repair bond strength of resin-based and hybrid CAD/CAM restorative materials. J. Adhes. Sci. and Technol.2020;1-14.

8. Blum IR, Lynch CD, Wilson NH. Factors influencing repair of dental restorations with resin composite. Clin. Cosmet. Investig. Dent. 2014;6:81-87.

9. Costa TR, Ferreira SQ, Klein-Junior CA, Loguercio AD, Reis A. Durability of surface treatments and intermediate agents used for repair of a polished composite. Oper. Dent. 2010;35:231-237.
10. Demarco FF, Corrêa MB, Cenci MS, Moraes RR, Opdam NJ. Longevity of posterior composite restorations: not only a matter of materials. Dent. Mater. 2012;28(1):87-101.

11. Duzyol M, Sagsoz O, Polat Sagsoz N, Akgul N, Yildiz M. The effect of surface treatments on the bond strength between CAD/CAM blocks and composite resin. J. Prosthodont. 2016;25(6):466-471.

12. Edelhoff D, Beuer F, Schweiger J, Brix O, Stimmelmayr $\mathrm{M}$, Güth JF. CAD/CAM-generated high-density polymer restorations for the pretreatment of complex cases: a case report. Quintessence. Int. 2012;43(6):457-467.

13. Elsaka SE. Repair bond strength of resin composite to a novel $\mathrm{CAD} / \mathrm{CAM}$ hybrid ceramic using different repair systems. Dent. Mater. J. 2015;34:161-167.

14. Gajewski VE, Pfeifer CS, Froes-Salgado NR, Boaro LC, Braga RR. Monomers used in resin composites: Degree of conversion, mechanical properties and water sorption/ solubility. Braz. Dent. J. 2012;23(5:)508-514.

15. Gul P, Altınok Uygun L. Repair bond strength of resin composite to three aged $\mathrm{CAD} / \mathrm{CAM}$ blocks using different repair systems. J. Adv. Prosthodont. 2020;12(3): 131-139.

16. Güngör MB, Nemli SK, Bal BT, Ünver S, Doğan A. Effect of surface treatments on shear bond strength of resin composite bonded to $\mathrm{CAD} / \mathrm{CAM}$ resin-ceramic hybrid materials. J. Adv. Prosthodont. 2016;8(4):259-266.

17. Jeong KW, Kim SH. Influence of surface treatments and repair materials on the shear bond strength of CAD/CAM provisional restorations. J. Adv. Prosthodont. 2019;11(2):95-104.

18. Kanzow P, Krois J, Wiegand A, Schwendicke F. Long-term treatment costs and cost-effectiveness of restoration repair versus replacement. Dent. Mater. 2021;37(6):375-381.

19. Kanzow P, Wiegand A, Schwendicke F, Göstemeyer G. Same, same, but different? A systematic review of protocols for restoration repair. J. Dent. 2019;86:1-16.

20. Kanzow P, Wiegand A, Schwendicke F. Cost-effectiveness of repairing versus replacing composite or amalgam restorations. J. Dent. 2016;54:41-47.

21. Kilinc H, Sanal FA, Turgut S. Shear bond strengths of aged and non-aged CAD/CAM materials after different surface treatments. J Adv Prosthodont, 2020;12(5):273-282.

22. Loomans BA, Özcan M. Intraoral repair of direct and indirect restorations: procedures and guidelines. Oper. Dent. 2016;41(7):68-78.

23. Melo MA, Moysés MR, Santos SG, Alcântara CE, Ribeiro JC. Effects of different surface treatments and accelerated artificial aging on the bond strength of composite resin repairs. Braz. Oral. Res. 2011;25(6):485-491.

24. Nassoohi N, Kazemi H, Sadaghiani M, Mansouri M, Rakhshan V. Effects of three surface conditioning techniques on repair bond strength of nanohybrid and nanofilled composites. Dent. Res. J. (Isfahan). 2015;12(6):554-561.

25. Özcan M, Corazza PH, Marocho SM, Barbosa SH, Bottino MA. Repair bond strength of microhybrid, nanohybrid and nanofilled resin composites: effect of substrate resin type, surface conditioning and ageing. Clin. Oral. Investig. 2013;17(7):1751-1758. 
26. Ozcan M, Raadschelders J, Vallittu P, Lassilla L. Effect of particle deposition parameters on silica coating of zirconia using a chairside air-abrasion device. J. Adhes. Dent. 2013;15(3):211-4.

27. Rekow ED, Silva NR, Coelho PG, Zhang Y, Guess P, Thompson VP. Performance of dental ceramics: challenges for improvements. J. Dent. Res. 2011;90(8):937-952.

28. Rinastiti M, Özcan M, Siswomihardjo W, Busscher HJ. Effects of surface conditioning on repair bond strengths of non-aged and aged microhybrid, nanohybrid, and nanofilled composite resins. Clin. Oral. Investig. 2011;15(5):625-633.

29. Rodrigues SA Jr, Ferracane JL, Della Bona A. Influence of surface treatments on the bond strength of repaired resin composite restorative materials. Dent. Mater. 2009;25(4):442-451.

30. Sismanoglu S, Tugce Gurcan A, Yildirim $\square$ Bilmez Z, Gumustas, B. Mechanical properties and repair bond strength of polymer $\square$ based CAD/CAM restorative materials. Int. J. Appl. Ceram. Technol. 2021;18(2):312-318.

31. Sismanoglu S, Yildirim-Bilmez Z, Erten-Taysi A, Ercal P. Influence of different surface treatments and universal adhesives on the repair of CAD-CAM composite resins: An in vitro study. J. Prosthet. Dent. 2020;124(2):238.e1-238. e9.
32. Stawarczyk B, Krawczuk A, Ilie N. Tensile bond strength of resin composite repair in vitro using different surface preparation conditionings to an aged $\mathrm{CAD} / \mathrm{CAM}$ resin nanoceramic. Clin. Oral. Investig. 2015;19(2):299-308.

33. Strasser T, Preis V, Behr M, Rosentritt M. Roughness, surface energy, and superficial damages of CAD/CAM materials after surface treatment. Clin. Oral. Investig. 2018;22(8):2787-2797.

34. Valente LL, Silva MF, Fonseca AS, Münchow EA, Isolan CP, Moraes RR. Effect of diamond bur grit size on composite repair. J. Adhes. Dent. 2015;17(3):257-263.

35. Vianna ALSV, Prado CJ, Bicalho AA, Pereira RAS, Neves FD, Soares CJ. Effect of cavity preparation design and ceramic type on the stress distribution, strain and fracture resistance of CAD/CAM nlays in molars. J. Appl. Oral. Sci. 2018;26:1-10

36. Zakavi F, Johar N, Moalemnia M, Rakhshan V. Effects of at-home and in-office bleaching and three composite types (hybrid, microhybrid, and nanofilled) on repair shear bond strength of aged composites: A preliminary study. Dent. Res. J. (Isfahan). 2021;18:61.

37. Zanatta RF, Lungova M, Borges AB, Torres C, Sydow HG, Wiegand A. Microleakage and shear bond strength of composite restorations under cycling conditions. Oper. Dent. 2017;42(2):71-80. 